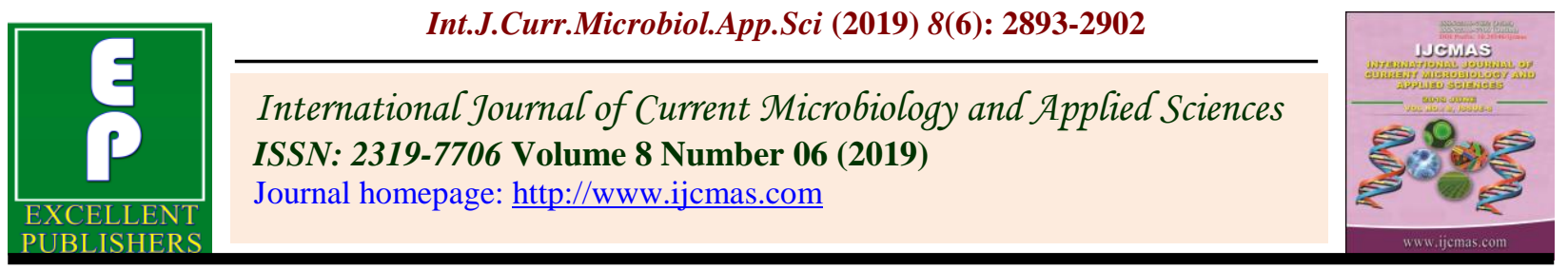

Original Research Article

https://doi.org/10.20546/ijcmas.2019.806.348

\title{
Application of Chemically Modified Chitosan for Removal of Arsenic from Water: A Column Bed Experiment
}

\author{
Ashutosh Kumar Singh ${ }^{1 *}$, S.P. Shukla ${ }^{1}$, Saurav Kumar ${ }^{1}$, \\ Priyanka Sahu and Neeraj Kumar ${ }^{2}$
}

${ }^{1}$ Aquatic Environment and Health Management Division, ICAR-Central Institute of Fisheries Education, Panch Marg, Off Yari Road, Versova, Mumbai, Maharastra-400061, India

${ }^{2}$ School of Edaphic Stress Management, ICAR-National Institute of Abiotic Stress Management,Malegaon, Baramati- 413 115, Pune Maharashtra, India

*Corresponding author

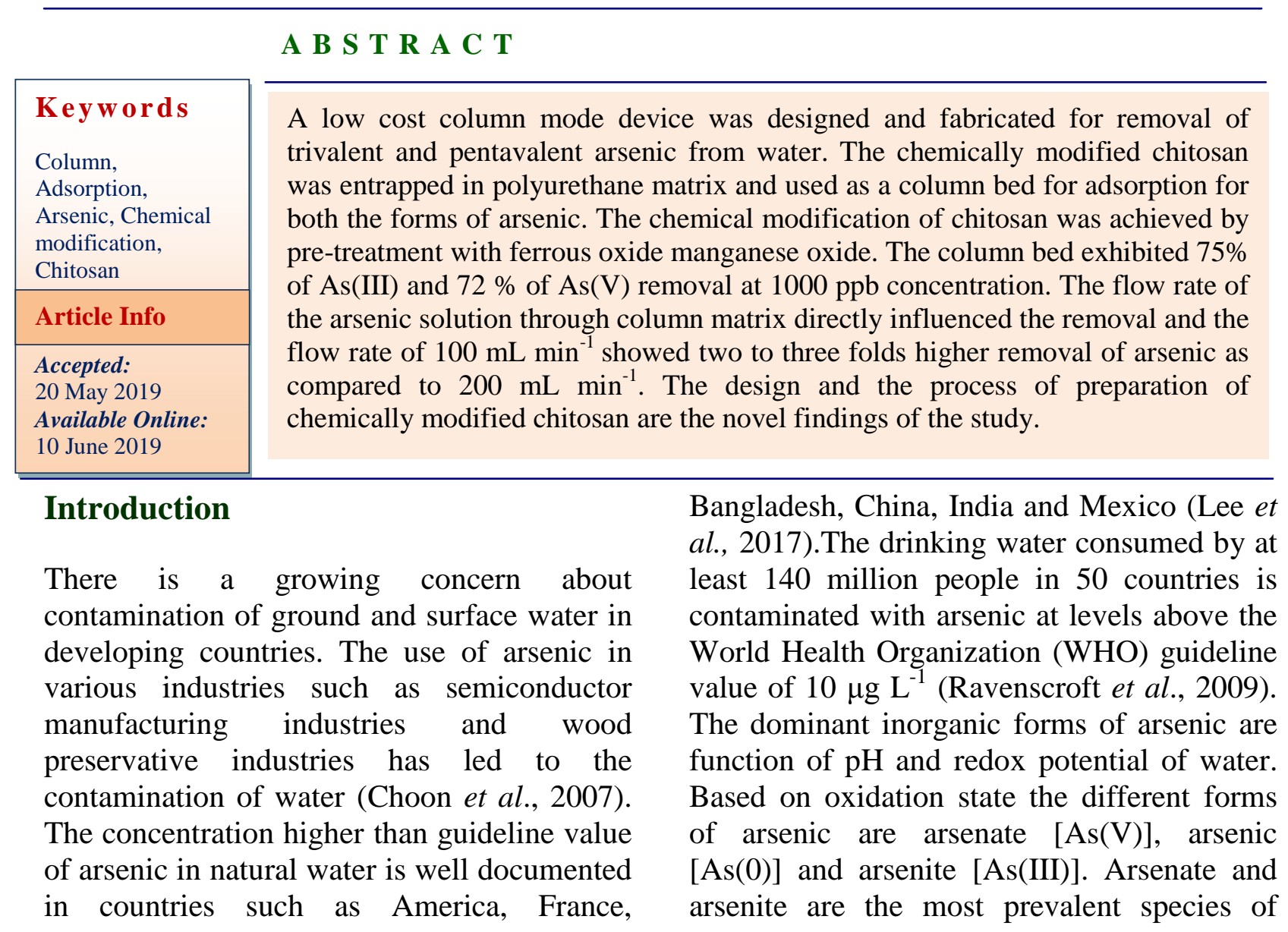


arsenic, commonly encountered in water (Pouset al., 2015). Higher cytotoxicity, genotoxicity, mobility and solubility have led to higher toxicity of arsenite compared to arsenate (Singh et al., 2015). Many treatment methods were tried for removal of arsenic from water but adsorption is the most preferred method due to availability of variety of low-cost adsorbent, low waste generation and ease of operation (Kabir and Chowdhary, 2017).

Chitosan is a polysaccharide obtained by hydrolysis of chitin using alkali. It is nontoxic, renewable and hydrophilic compound (Elwakeel, 2010). Chitosan is considered as a better adsorbent than chitin due to the presence of many amino $\left(-\mathrm{NH}_{2}\right)$ groups which act as reaction sites for binding with arsenic (Annadurai et al., 2008). It is also considered as a low-cost adsorbent due to the availability of its raw material in plenty and also as a byproduct of crustacean shell and fungal biomass

The present study aimed to fabricate a lowcost column mode device by using PVC pipe. The adsorbent bed of the column was prepared by chemical modification of chitosan using ferrous oxide and manganese oxide and used for arsenite [As(III)] and arsenate $[\mathrm{As}(\mathrm{V})]$ removal from water. The efficacy of the column was evaluated through column experiments on the basis of the parameters such as removal efficiency, adsorption capacity and breakthrough ratio.

\section{Materials and Methods}

\section{Design of column}

The filtration unit used for the present study was developed and fabricated from locally available material. Low cost and locally available materials like polyurethane foam, PVC pipes and plastic containers were used for the fabrication of the unit. The unit consisted of two compartments (upper and lower), and a column consisting of adsorbent materials which was placed at the junction of both the compartment with a vertical orientation. The column was in contact with an untreated arsenic solution of the upper compartment through the inlet channel. The treated water was discharged into the lower compartment after passing through the column. The simplified column is shown in (Fig. 1).

\section{Packing material of column for arsenic removal}

The column packing material was prepared by entrapping the chemically modified chitosan into the polyurethane foam. The foam was cut into a cylindrical shape. Two foams entrapped with the chemically modified chitosan were used to prepare the column for the experiment. The dimension (diameter $\mathrm{x}$ height) of foam material used in the experiment was 7.5 and $6.5 \mathrm{~cm}$ respectively.

The packing material for the column was prepared by soaking the polyurethane foam with the chemically modified chitosan which was prepared by the following procedure of Zhang et al., (2007) and Miller and Zimmerman (2010) with a slight modification. The total weight of adsorbent for each polyurethane foam was $10 \mathrm{~g}$. The polyurethane foams are then soaked in $0.01 \mathrm{M}$ $\mathrm{NaOH}$ and washed with distilled water until the filtrate becomes neutral. Polyurethane foams were then dried and kept for later use in the experiment.

\section{Column experiment}

Column experiment for removal of As(III) and $\mathrm{As}(\mathrm{V})$ was conducted using column consisting of polyurethane foam entrapped with the chemically modified chitosan. The 
required working test concentration of As(III) and $\mathrm{As}(\mathrm{V})$ was prepared from the stock solution of both forms of arsenic and filtered through the column.

The experiment was conducted by passing $1000 \mathrm{ppb}$ of $\mathrm{As}(\mathrm{III})$ and $\mathrm{As}(\mathrm{V})$ solution through the designed column for $180 \mathrm{~min}$ at a flow rate of $100 \mathrm{~mL} \mathrm{~min}^{-1}$. The effect of the flow rate of the column on its performance was also studied at 100 and $200 \mathrm{~mL} \mathrm{~min}^{-1}$. The samples were collected at 15, 30, 45, 60, $90,120,150$, and $180 \mathrm{~min}$ post operational from the column and filtrate was analyzed for arsenic content. The removal efficiency, adsorption capacity and breakthrough ratio were calculated and compared for As(III) and $\mathrm{As}(\mathrm{V})$ at each time period. The arsenic concentrations before and after adsorption were estimated. Further, the removal efficiency of the column was computed using the standard equation (Das and Mondal, 2011).

\section{Removal efficiency $=\left[C_{0}-C_{\theta} / C_{0}\right] \times 100$}

Where $\mathrm{C}_{0}$ and $C_{e}$ are the concentration of arsenic before and after the treatment.

The adsorption capacity $\left(\mathrm{q}_{\mathrm{e}}=\mathrm{mg} \mathrm{g}^{-1}\right)$ of the column for each concentration of arsenic [As(III) and As(V)] at equilibrium was also determined by using the following equation (Das and Mondal, 2011):

Adsorption capacity $=\frac{\left[\left(C_{0}-C_{i}\right) V\right]}{M}$

Where,

$\mathrm{V}$ is the volume of solution (L) and $\mathrm{M}$ is the mass of the adsorbent $(\mathrm{g})$.

The breakthrough ratio of $\mathrm{As}(\mathrm{III})$ and $\mathrm{As}(\mathrm{V})$ during the column experiment at various time interval was calculated by taking the ratio of effluent concentration $\left(C_{e}\right)$ and influent concentration $\left(\mathrm{C}_{0}\right)$ against time. The ratio value of 1.0 denoted the breakthrough point.

\section{Arsenic analysis}

As(III) and As(V) in the water before and after treatment were analyzed using Inductively Coupled Plasma Mass Spectrometry (ICP-MS). Briefly, a Perkin Elmer ELAN DRC instrument was used with a meinhart nebulizer and silica cyclonic spray chamber and continuous nebulization. The operating conditions were Nebulizer Gas flow rates: $0.95 \mathrm{~L} \mathrm{~min}^{-1}$; Auxiliary Gas Flow: 1.2 $\mathrm{L} \mathrm{min}^{-1}$; Plasma Gas Flow: $15 \mathrm{~L} \mathrm{~min}^{-1}$; Lens Voltage: $7.25 \mathrm{~V}$; ICP RF Power: $1100 \mathrm{~W}$; $\mathrm{CeO} / \mathrm{Ce}=0.031 ; \mathrm{Ba}^{++} / \mathrm{Ba}^{+}=0.016$.

\section{Results and Discussion}

\section{Removal efficiency of column with increase in time}

The result showed that the removal efficiency of column (Fig. 2) decreased with increase in time for both As(III) and As(V). The removal efficiency decreased from 75 to $9 \%$ in 15 to $180 \mathrm{~min}$ period for As(III). A similar trend was observed for $\mathrm{As}(\mathrm{V})$ where the decrease in removal efficiency was 72 to $4 \%$ in 15 to 180 min column operation time. It was also observed that removal efficiency of the column for As(III) was higher at all the time (15 to $180 \mathrm{~min}$ ) when compared for $\mathrm{As}(\mathrm{V})$. The overall decrease in column removal efficiency with increase in time for both $\mathrm{As}(\mathrm{III})$ and $\mathrm{As}(\mathrm{V})$ is due to reduction in vacant sites of adsorbents with increase in time.

\section{Adsorption capacity of column with} increase in time

The result showed there was an increase in adsorption capacity of column in the initial 
phase but a gradual decrease in adsorption capacity was evident after initial 15 minutes (Fig. 3). The adsorption capacity increased 0.05 to $0.09 \mathrm{mgg-}^{1}$ till $60 \mathrm{~min}$ of operation of the column for As(III). Also the adsorption capacity started decreasing after $60 \mathrm{~min}$ of column operation time and reached from 0.09 to $0.05 \mathrm{mg} \mathrm{g}^{-1}$ at the end of the column experiment $(180 \mathrm{~min})$. The same trend was also observed for As(V), but the increase was found only upto $30 \mathrm{~min}$ of column operation time and after that it gradually decreased. The adsorption capacity increased from 0.05 to 0.9 $\mathrm{mg} \mathrm{g}^{-1}$ till $30 \mathrm{~min}$ and then decreased to 0.02 at the end of experiment $(180 \mathrm{~min})$. The above trend is due to shortening of mass transfer zone after a initial time period which resulted in a decrease in adsorption capacity after attaining maximum value.

\section{Breakthrough ratio of column with increase in time}

The breakthrough ratio of the column showed that it increased with the column operation time (Fig. 4). The breakthrough ration increased from 0.25 to 0.91 in 15 to $180 \mathrm{~min}$ of column operation time for As(III). The same trend was also observed for $\mathrm{As}(\mathrm{V})$ where the breakthrough ration increased from 0.28 to 0.96 in 15 to $180 \mathrm{~min}$ of column operation time. It was also observed that the breakthrough ration was always higher for As(V) when compared for As(III). The increase in breakthrough ratio is due to the increase in amount of adsorbate (arsenite and arsenate) on the column bed, which reduces the capacity of adsorption of the adsorbent.

\section{Effect of column flow rate on removal efficiency of column}

It was noticed that with increase in flow rate of the column, there was decrease in removal efficiency of the column (Table 1) for both As(III) and As(V). The removal efficiency of column decreased from 80 to $30 \%$ at flow rate of $100 \mathrm{~mL} \mathrm{~min}^{-1}$, while it reduced from 32 to $10.2 \%$ at flow rate of $200 \mathrm{~mL} \mathrm{~min}{ }^{-1}$ for As(III) between 15-180 min. In case of As(V) the removal rate decreased from 76 to $26 \%$ at $100 \mathrm{~mL} \mathrm{~min}^{-1}$ and 30 to $8 \%$ at $200 \mathrm{~mL} \mathrm{~min}^{-1}$ between 15-180 min. The result showed that there was almost two to three-fold decrease in removal efficiency of column for both As(III) and $\mathrm{As}(\mathrm{V})$ due to increase in flow rate from $100 \mathrm{~mL} \mathrm{~min}^{-1}$ to $200 \mathrm{~mL} \min ^{-1}$.The decrease in removal efficiency with increase in flow rate is due to availability of insufficient time for both forms of arsenic to interact with the column bed (Nidheesh et al., (2012).

Table.1 Removal efficiency (\%) of column at different flow rate for As(III) and As(V) at different time period. [Adsorbent mass: 20g, Initial concentration: $500 \mathrm{ppb}, \mathrm{pH}: 7 \pm 0.5$, Temperature: $27 \pm 2{ }^{\circ} \mathrm{C}$ ]. Data are presented in Mean \pm S.E, $n=2$.

\begin{tabular}{|c|c|c|c|c|}
\hline Time (min) & \multicolumn{2}{|c|}{ As(III) } & \multicolumn{2}{|c|}{$\operatorname{As}(\mathbf{V})$} \\
\hline & $100 \mathrm{~mL} \min ^{-1}$ & $200 \mathrm{~mL} \min ^{-1}$ & $100 \mathrm{~mL} \min ^{-1}$ & $200 \mathrm{~mL} \min ^{-1}$ \\
\hline 15 & $80 \pm 0.0022$ & $32.0 \pm 0.0033$ & $76.0 \pm 0.0028$ & $30.0 \pm 0.0043$ \\
\hline 30 & $76 \pm 0.0030$ & $28.0 \pm 0.0020$ & $72.0 \pm 0.0031$ & $26.0 \pm 0.0040$ \\
\hline 45 & $72 \pm 0.0035$ & $24.8 \pm 0.0015$ & $68.0 \pm 0.0030$ & $23.0 \pm 0.0015$ \\
\hline 60 & $66 \pm 0.0039$ & $22.0 \pm 0.0029$ & $62.0 \pm 0.0038$ & $21.0 \pm 0.0069$ \\
\hline 90 & $54 \pm 0.0056$ & $20.0 \pm 0.0031$ & $50.0 \pm 0.0023$ & $18.0 \pm 0.0021$ \\
\hline 120 & $46 \pm 0.0023$ & $18.0 \pm 0.0049$ & $38.0 \pm 0.0027$ & $14.0 \pm 0.0029$ \\
\hline 150 & $38 \pm 0.0035$ & $13.6 \pm 0.0052$ & $32.0 \pm 0.0019$ & $10.0 \pm 0.0032$ \\
\hline 180 & $30 \pm 0.0058$ & $10.2 \pm 0.0016$ & $26.0 \pm 0.0024$ & $8.0 \pm 0.0036$ \\
\hline
\end{tabular}


Fig.1 Diagram of column

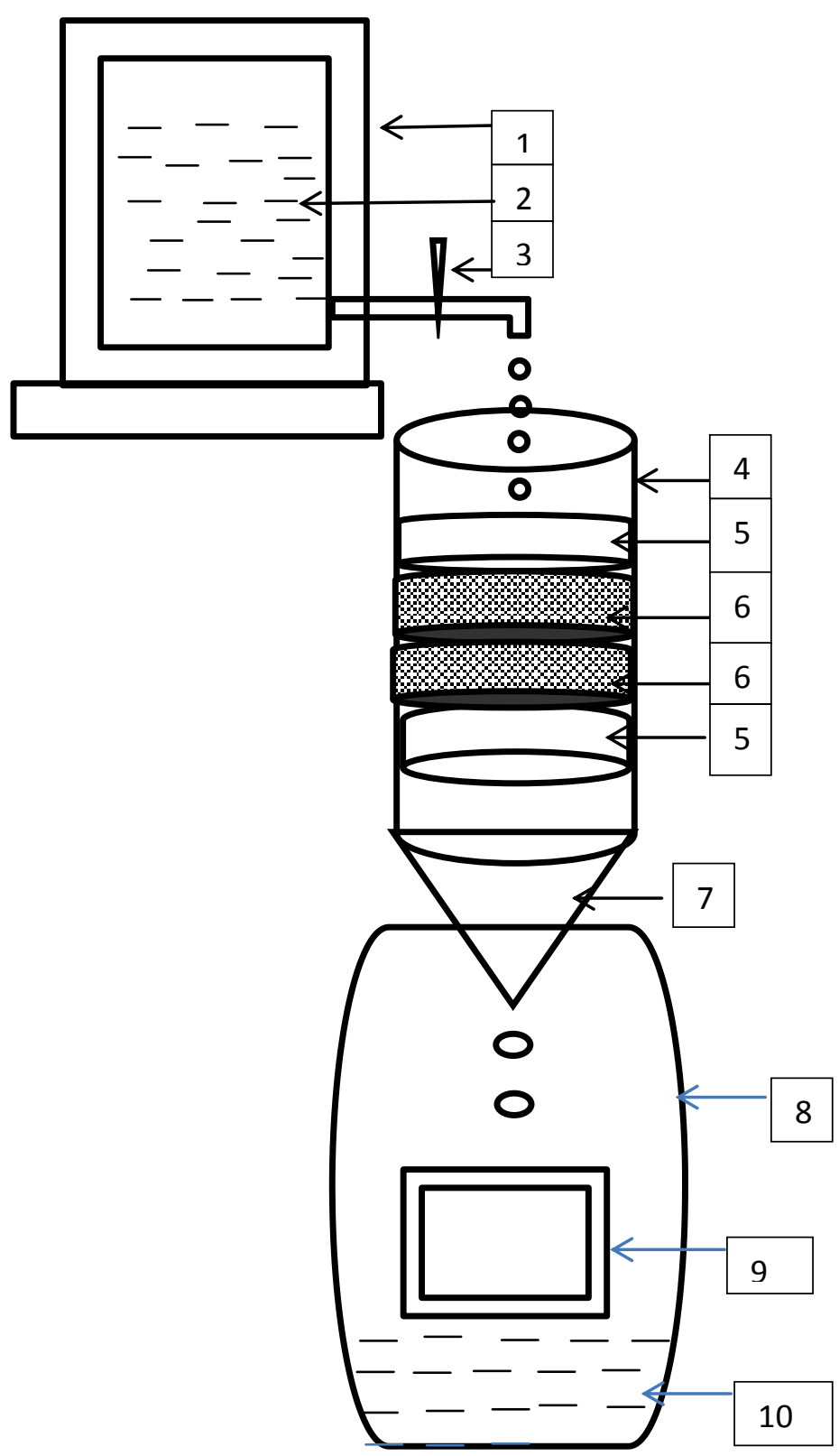

1- Water tank

2- Arsenic contaminated water

3- Water flow regulator

4- PVC pipe

5- Polyurethane foam
6- Treated polyurethane foam

7- Funnel plastic for effluent exit

8- Water container

9- Window for collection of sample

10- Treated water 
Fig.2 Removal efficiency of column for As(III) and $\mathrm{As}(\mathrm{V})$ at different time period [Adsorbent mass: $20 \mathrm{~g}$, Initial concentration: $1000 \mathrm{ppb}, \mathrm{pH}: 7 \pm 0.5$, Temperature: $27 \pm 2{ }^{\circ} \mathrm{C}$, Flow rate:

$100 \mathrm{~mL} \mathrm{~min}^{-1}$ ]. Data are presented in Mean \pm S.E., $\mathrm{n}=2$

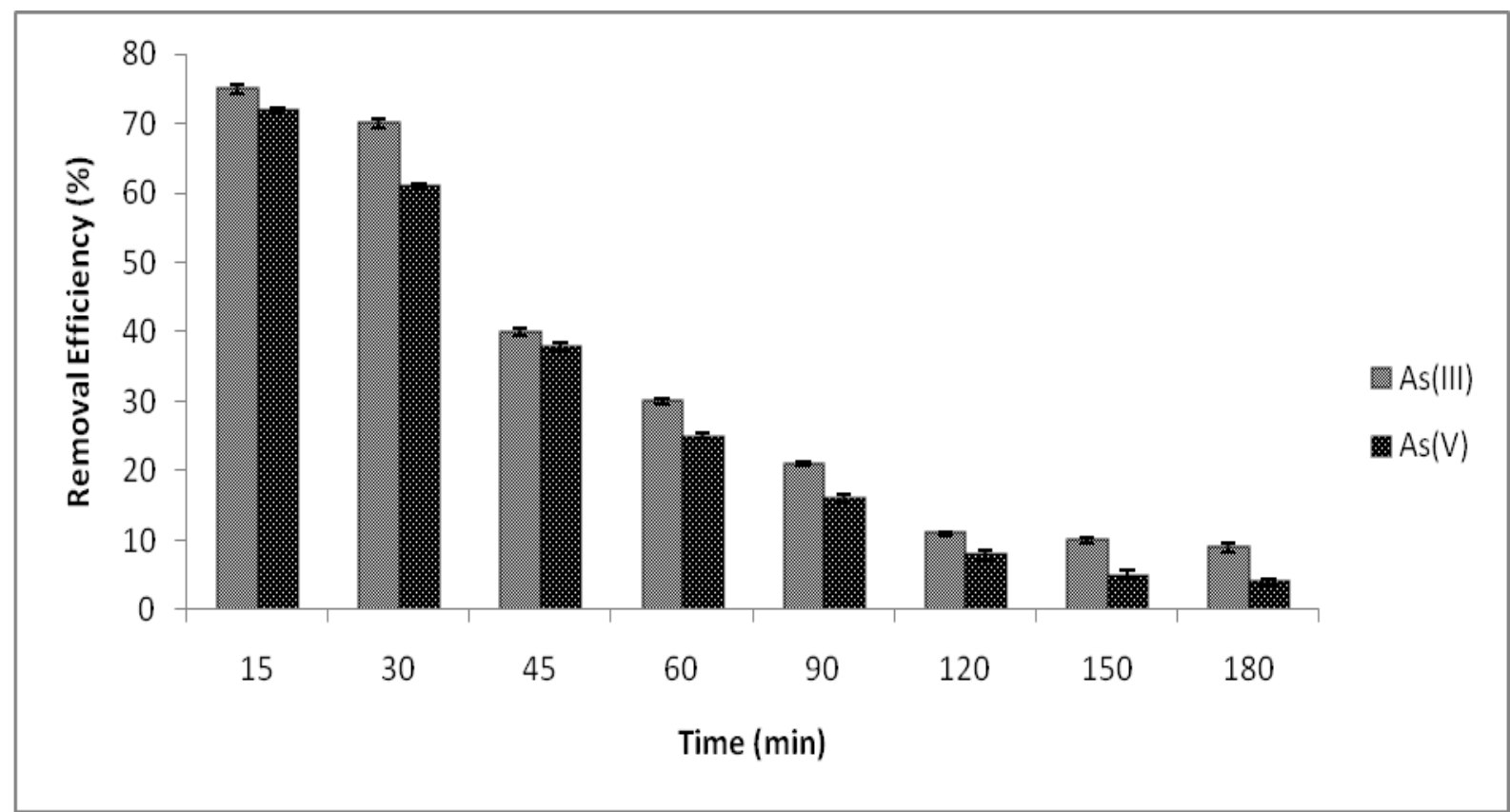

Fig.3 Adsorption capacity of column for As(III) and As(V) at different time period [Adsorbent mass: $20 \mathrm{~g}$, Initial concentration: $1000 \mathrm{ppb}, \mathrm{pH}: 7 \pm 0.5$, Temperature: $27 \pm 2{ }^{0} \mathrm{C}$, Flow rate:

$100 \mathrm{~mL} \mathrm{~min}^{-1}$ ]. Data are presented in Mean \pm S.E., $\mathrm{n}=2$

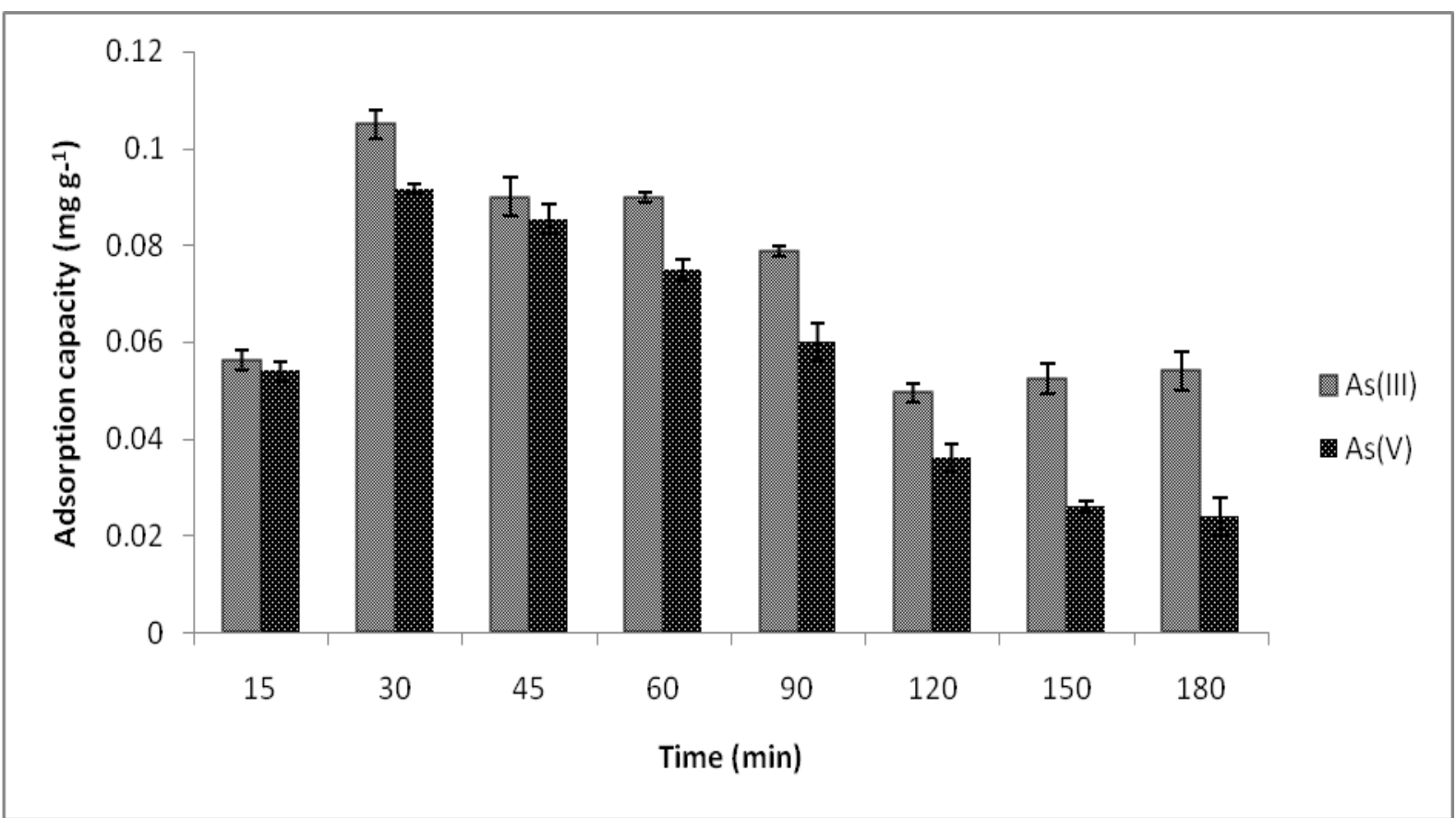


Fig.4 Breakthrough ratio of column for $\mathrm{As}(\mathrm{III})$ and $\mathrm{As}(\mathrm{V})$ at different time period [Adsorbent mass: $20 \mathrm{~g}$, Initial concentration: $1000 \mathrm{ppb}, \mathrm{pH}: 7 \pm 0.5$, Temperature: $27 \pm 2{ }^{\circ} \mathrm{C}$, Flow rate:

$\left.100 \mathrm{~mL} \mathrm{~min}^{-1}\right]$. Data are presented in Mean \pm S.E., $\mathrm{n}=2$

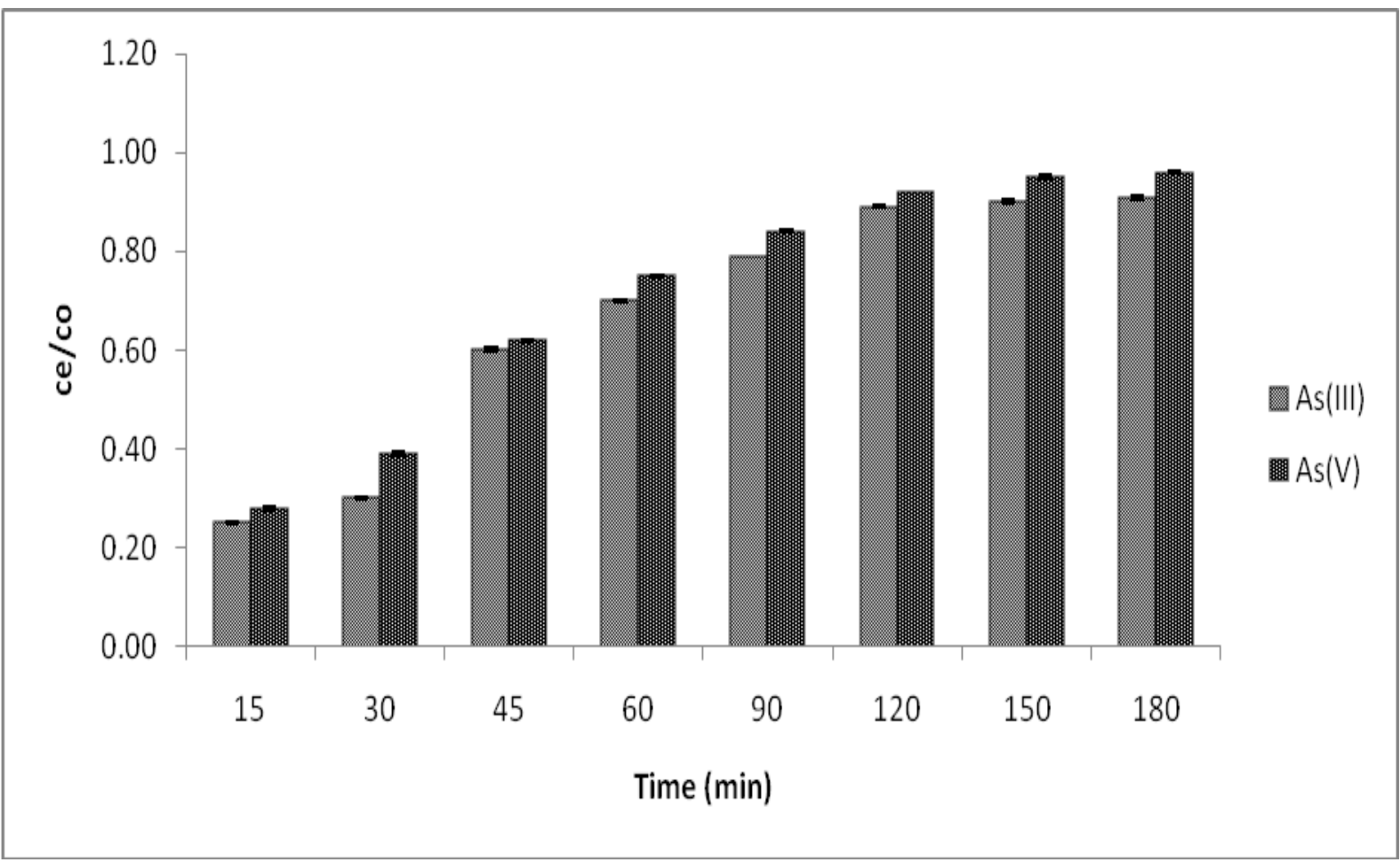

Fig.5 Adsorption capacity of column at different flow rate for $\mathrm{As}(\mathrm{III})$ and $\mathrm{As}(\mathrm{V})$ at different time period. [Adsorbent mass: 20g, Initial concentration: $500 \mathrm{ppb}, \mathrm{pH}: 7 \pm 0.5$, Temperature: $27 \pm 2$

$\left.{ }^{0} \mathrm{C}\right]$. Data are presented in Mean \pm S.E, $\mathrm{n}=2$

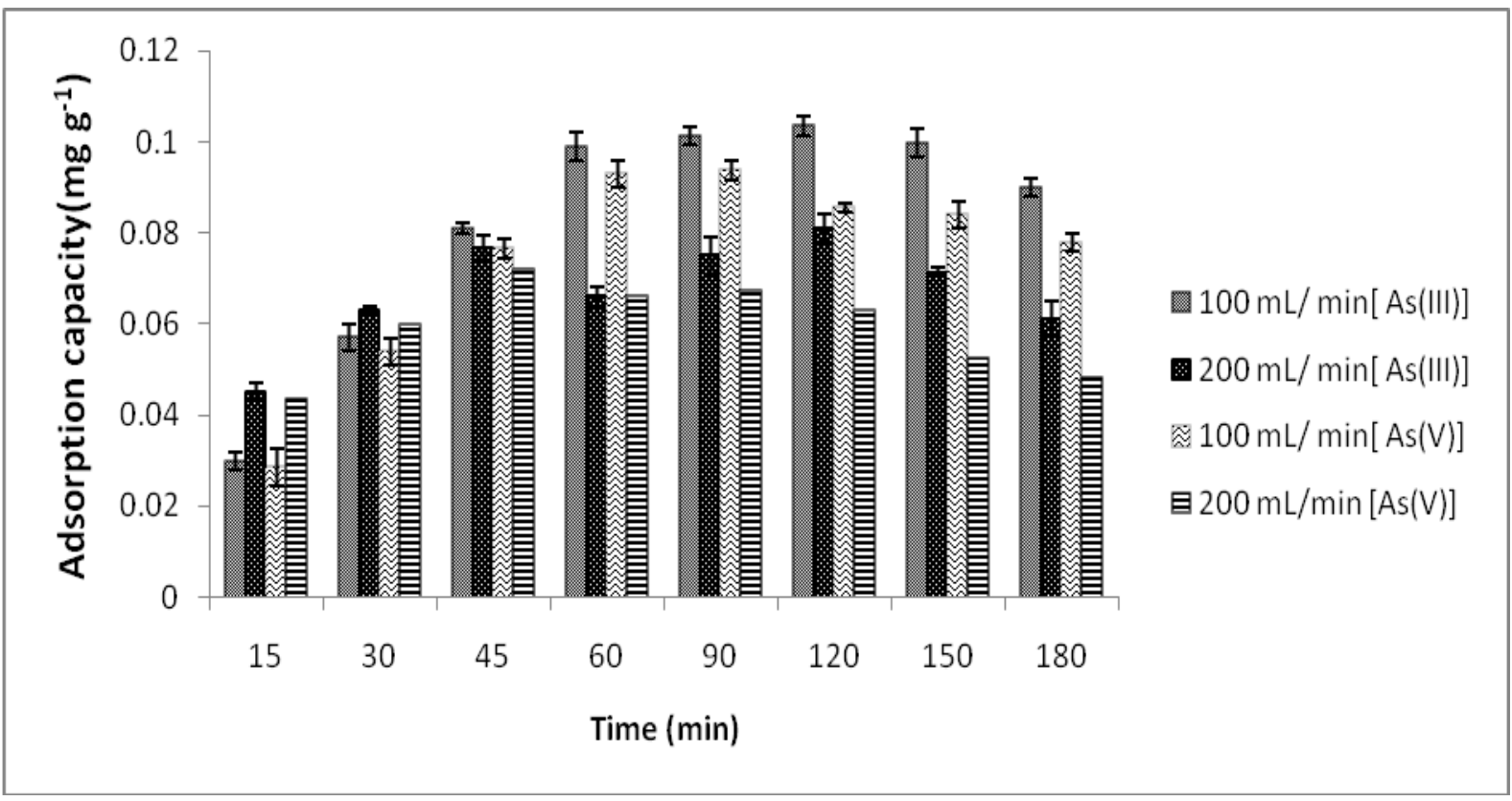


Fig.6 Breakthrough ratio of column at different flow rate for $\mathrm{As}(\mathrm{III})$ and $\mathrm{As}(\mathrm{V})$ at different time period. [Adsorbent mass: 20g, Initial concentration: $500 \mathrm{ppb}, \mathrm{pH}: 7 \pm 0.5$, Temperature: $27 \pm 2$

$\left.{ }^{0} \mathrm{C}\right]$. Data are presented in Mean \pm S.E, $\mathrm{n}=2$

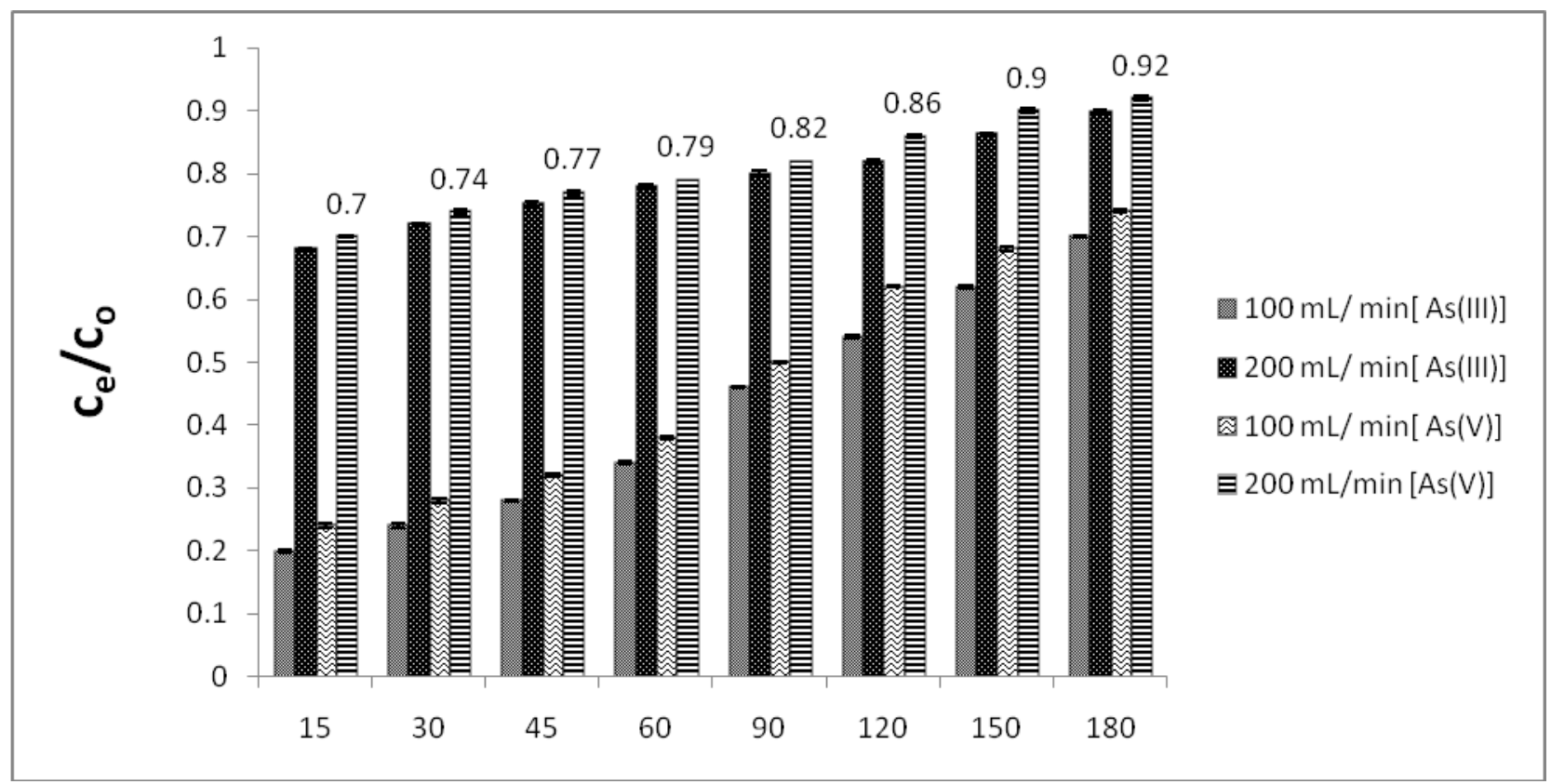

Effect of column flow rate on adsorption capacity of column

It was found that with increase in flow rate from 100 to $200 \mathrm{~mL} \mathrm{~min}{ }^{-1}$, the adsorption capacity decreased after 30 min of column operation for As(III). The adsorption capacity was found to be higher at $200 \mathrm{~mL} \mathrm{~min}^{-1}$ till 30 min of column operation time when compared to flow rate of $100 \mathrm{~mL} \mathrm{~min}{ }^{-1}$ (Fig. 5). The adsorption capacity increased from 0.03 to $0.10(15-120 \mathrm{~min})$ and then decreased to 0.09 (180 min) at $100 \mathrm{~mL} \mathrm{~min}^{-1}$ for As(III). But at $200 \mathrm{~mL} \mathrm{~min}^{-1}$ for $\mathrm{As}(\mathrm{III})$, the adsorption capacity increased from 0.04 to 0.08 (15 -120 min) and then decreased to 0.06 (180 min). The same trend was also observed for As (V) where the adsorption capacity was higher at flow rate of $200 \mathrm{~mL} \mathrm{~min}{ }^{-1}$ till $30 \mathrm{~min}$ of column operation. A gradual decrease in the adsorption capacity of the column at $200 \mathrm{~mL}$ $\min ^{-1}$ was recorded after $30 \mathrm{~min}$. The adsorption capacity was $0.02 \mathrm{mg} \mathrm{g}^{-1}$ at 15 min, 0.09 at $90 \mathrm{~min}$ and then finally reached to 0.07 after $180 \mathrm{~min}$ for $\mathrm{As}(\mathrm{V})$ at flow rate of $100 \mathrm{~mL} \mathrm{~min}^{-1}$. In case of As(V), flow rate of $200 \mathrm{~mL} \mathrm{~min}^{-1}$ showed that the adsorption capacity increased from $0.04 \mathrm{mg} \mathrm{g}^{-1}$ (15 min) to $0.07 \mathrm{mg} \mathrm{g}^{-1}$ (45 min) and then decreased to $0.04 \mathrm{mg} \mathrm{g}^{-1}(180 \mathrm{~min})$. The increase in adsorption capacity up to certain time is attributed to the higher availability of vacant sites on the adsorbent. The decrease in removal efficiency of column might be also due to decrease in bonding capacity of arsenic ions onto the adsorbent surface with increase in flow rate. Similar findings were reported by Roy et al., (2013) who stated that adsorption capacity decreased when the flow rate increased from 3 to $7 \mathrm{~mL} \mathrm{~min}^{-1}$.

\section{Effect of column flow rate on breakthrough ratio of column}

The breakthrough ratio shows it was comparatively higher for both As(III) and

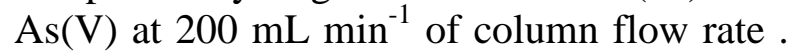
The breakthrough ratio increased from 0.2 (15 
$\min )$ to $0.7(180 \mathrm{~min})$ at flow rate of $100 \mathrm{~mL}$ $\min ^{-1}$, while the increase was from 0.68 (15 $\mathrm{min}$ ) to 0.89 (180 $\mathrm{min}$ ) for $200 \mathrm{~mL} \mathrm{~min}^{-1}$ (Fig. 6) for $\mathrm{As}(\mathrm{V})$. At flow rate of 100 and $200 \mathrm{~mL}$ $\mathrm{min}^{-1}$ for $\mathrm{As}(\mathrm{V})$, the breakthrough ratio increase from $0.24(15 \mathrm{~min})$ to $0.74(180 \mathrm{~min})$ and $0.7(15 \mathrm{~min})$ to $0.92(180 \mathrm{~min})$ respectively. The increase in breakthrough ratio with increase in flow rate is explained by the fact that as the flow rate increased, the time required for the adsorbate (arsenic) to interact with the column bed decreases and thus the concentration of arsenic after treatment decreases slowly. It was also observed that at higher flow rate saturation of column will occur more slowly when compared to lower flow rate. Rouf and Nagapadma, (2015) also reported that at higher flow rate saturation of column was delayed in case of azo dye adsorption on chitosan impregnated with a cationic surfactant.

In conclusion, chemical modification of Chitosan showed an improved efficiency for the removal of trivalent and pentavalent arsenic from water. The entrapment of the chemically modified chitosan in the column matrix exhibited an appreciable extent of removal of arsenic from water. The column bed device was fabricated from widely available low-cost materials therefore, the developed device offers an effective solution for remediation of arsenic contaminated water.

\section{Acknowledgment}

Authors are thankful to the Director of Central Institute of Fisheries Education Mumbai and Director, National Institute of Abiotic Stress Management, Baramati, India for providing all the facilities related to research work. The fund provided by the Indian Council of Agricultural Research, New Delhi, for the research work is also acknowledged.

\section{References}

Annadurai, G., Ling, L.Y. and Lee, J.F. (2008). Adsorption of reactive dye from an aqueous solution by chitosan: isotherm, kinetic and thermodynamic analysis. J. Hazard. Mater.152, 337346.

Choong, T.S.Y., Chuah, T.G., Robiah, Y., Koay, F.L.G. and Azni, I. (2007) Arsenic toxicity, health hazards and removal techniques from water: an overview. Desalination 217:139-166

Das, B. and Mondal, N.K. (2011). Calcareous soil as a new adsorbent to remove lead from aqueous solution: equilibrium, kinetic and thermodynamic study. Uni. J. Environ. Res. Technol. 1, 515-530.

Elwakeel, K.Z. (2010). Environmental application of chitosan resins for the treatment of water and wastewater: a review. J. Dispersion Sci. Technol. 31, 273-288.

Kabir, F. and Chowdhury, S. (2017). Arsenic removal methods for drinking water in the developing countries: technological developments and research needs. Environ Sci Pollut Res 24:24102-24120

Lee, C.G., Alvarez, P.J., Nam, A., Park, S.J., Do, T., Choi, U.S. and Lee, S.H. (2017). Arsenic (V) removal using an aminedoped acrylic ion exchange fiber: kinetic, equilibrium, and regeneration studies. J. Hazard. Mater. 325, 223229.

Miller, S.M. and Zimmerman, J.B. (2010). Novel, bio-based, photoactive arsenic sorbent: $\quad \mathrm{TiO}_{2}$-impregnated chitosan bead. Water Res. 44, 5722-5729.

Pous, N., Casentini, B., Rossetti, S., Fazi, S., Puig, S. and Aulenta, F.(2015). Anaerobic arsenite oxidation with an electrode serving as the sole electron acceptor: a novel approach to the bioremediation of arsenic-polluted groundwater. J. Hazard. Mater. 283, 617-622. 
Rouf, S. and Nagapadma, M. (2015). Modeling of fixed-bed column studies for adsorption of azo dye on chitosan impregnated with a cationic surfactant. Int. J. Sci. Eng. Res. 6(2), 124-132.

Nidheesh, P.V., Gandhimathi, R., Ramesh, S.T. and Singh, T.S.A. (2012). Adsorption and desorption characteristics of crystal violet in bottom ash column, J. Urban Env. Eng. 6(1): 18-29.

Roy, P., Mondal, N.K., Bhattacharya, S., Das, B. and Das, K.(2013). Removal of arsenic (III) and arsenic (V) on chemically modified low-cost adsorbent: batch and column operations. Appl.Wat. Sci. 3(1): 293-309

Ravenscroft, P., Brammer, H. and Richards, K. (2009). Arsenic pollution: a global synthesis (Vol. 28). John Wiley \& Sons.

Singh, R., Singh, S., Parihar, P., Singh, V.P. and Prasad, S.M. (2015). Arsenic contamination, consequences and remediation techniques: a review. Ecotoxicol. Environ. Saf.112, 247-270.

Zhang, G., Qu, J., Liu, H., Liu, R. and Wu, R.(2007). Preparation and evaluation of a novel $\mathrm{Fe}-\mathrm{Mn}$ binary oxide adsorbent for effective arsenite removal. Wat. Res. 41(9): 1921-1928.

\section{How to cite this article:}

Ashutosh Kumar Singh, S.P. Shukla, Saurav Kumar, Priyanka Sahu and Neeraj Kumar. 2019. Application of Chemically Modified Chitosan for Removal of Arsenic from Water: A Column Bed Experiment. Int.J.Curr.Microbiol.App.Sci. 8(06): 2893-2902.

doi: https://doi.org/10.20546/ijcmas.2019.806.348 